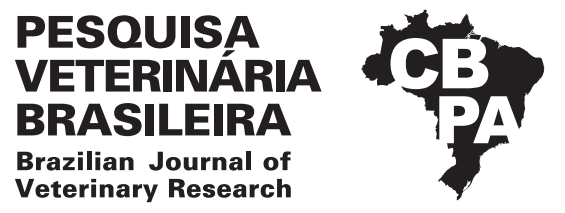

Pesq. Vet. Bras. 38(12):2262-2265, dezembro 2018 DOI: 10.1590/1678-5150-PVB-5914

Original Article

ISSN 0100-736X (Print)

ISSN 1678-5150 (Online)

\title{
Blackleg in a free-range brown brocket deer (Mazama gouazoubira) ${ }^{1}$
}

\author{
Joanna V.Z. Echenique ${ }^{2}{ }^{3}$, Mauro P. Soares ${ }^{3 *}$, Francisco A. Uzal ${ }^{4}$, Silvia R.L. Ladeira ${ }^{3}$, \\ Ana Paula N. Albano ${ }^{5}$, Paulo M. Bandarra ${ }^{6}$ and Ana Lucia Schild ${ }^{3}$
}

\begin{abstract}
Echenique J.V.Z., Soares M.P., Uzal F.A., Ladeira S.R.L., Albano A.P.N., Bandarra P.M. \& Schild A.L. 2018. Blackleg in a brown brocket deer (Mazama gouazoubira). Pesquisa Veterinária Brasileira 38(12):2262-2265. Laboratório Regional de Diagnóstico, Faculdade de Veterinária, Universidade Federal de Pelotas, Campus Capão do Leão, Pelotas, RS 96010900, Brazil. E-mail: gmpsoares@gmail.com

A case of blackleg in a brown brocket deer (Mazama gouazoubira) associated with trauma from being hit by a car in southern Rio Grande do Sul is reported. The clinical signs included fever, dehydration and lethargy that worsened progressively until 36 hours after the accident, when the animal died. In the fore right limb, there was a comminuted closed fracture of the radius and ulna but no skin wounds were observed. Grossly, the musculature of the pelvic limbs presented hemorrhage, edema and emphysema. Microscopically, the muscles of both rear legs had necrosis, edema, hemorrhage and mild inflammatory infiltration of neutrophils. Clostridium chauvoei was cultured from affected skeletal muscles, and it was also detected by immunohistochemistry, confirming a diagnosis of blackleg. The overlapping habitat of cattle and brown brocket deer is proposed as a predisposing factor in this case and alerts to spillover cases maybe happening in this region. In addition, blackleg should be included as differential diagnoses of deer with post-traumatic myositis.
\end{abstract}

INDEX TERMS: Blackleg, brown brocket deer, Mazama gouazoubira, Clostridium chauvoei, cervid, spillover, myositis, wildlife animals.

\section{RESUMO.- [Carbúnculo sintomático em veado virá de vida livre (Mazama gouazoubira).] Descreve-se um caso de carbúnculo sintomático em um veado-virá (Mazama gouazoubira), macho, jovem, resgatado após atropelamento em uma rodovia na região sul do Rio Grande do Sul. 0 cervídeo apresentou febre, desidratação e letargia,}

\footnotetext{
${ }^{1}$ Received on July $31,2018$.

Accepted for publication on August 16, 2018.

${ }^{2}$ Post-Graduate in Veterinary, Faculdade de Veterinária, Universidade Federal de Pelotas (UFPel), Campus Universitário Capão do Leão, Pelotas, RS 96010-900, Brazil.

${ }^{3}$ Laboratório Regional de Diagnóstico, Universidade Federal de Pelotas (UFPel), Campus Universitário Capão do Leão, Pelotas, RS 96010-900, Brazil. *Corresponding author: gmpsoares@gmail.com

${ }^{4}$ California Animal Health and Food Safety Laboratory System, University of California, Davis, San Bernardino, CA, USA.

${ }^{5}$ Hospiltal de Clínicas Veterinárias, Universidade Federal de Pelotas (UFPel), Campus Universitário Capão do Leão, Pelotas, RS 96010-900.

${ }^{6}$ Núcleo de Reabilitação da Fauna Silvestre (NURFS), Centro de Triagem de Animais Silvestres (CETAS), Universidade Federal de Pelotas (UFPel), Campus Capão do Leão, Pelotas, RS 96010-900.
}

progredindo para a morte em 36 horas. No membro torácico direito foi observado fratura cominutiva fechada de rádio e ulna sem a presença de feridas perfurantes. Na necropsia foi observada hemorragia, edema e enfisema na musculatura dos membros pélvicos. Microscopicamente, os músculos dos membros pélvicos apresentaram necrose, edema, hemorragia e discreto infiltrado inflamatório neutrofílico. Houve o isolamento de Clostridium chauvoei e marcação positiva na técnica de IHQ com anticorpo monoclonal anti-C. chauvoei, confirmando o diagnóstico de carbúnculo sintomático. A sobreposição de habitat entre bovinos domésticos e cervídeos pode ser um fator de risco para esta doença e chama a atenção para casos de "spillover" que podem estar ocorrendo na região. Adicionalmente, sugere-se que o carbúnculo sintomático seja incluído nos diagnósticos diferenciais de cervídeos que apresentam miosite pós-traumática.

TERMOS DE INDEXAÇÃO: Carbúnculo sintomático, veado virá, vida livre, Mazama gouazoubira, Clostridium chauvoei, cervídeo, spillover, miosite, animais silvestres. 


\section{INTRODUCTION}

Blackleg is a clostridial disease characterized by necrotizing myositis and caused by Clostridium chauvoei, which leads to significant economic losses in cattle around the world (Maboni et al. 2010, Abreu \& Uzal 2016, Abreu et al. 2017), including Brazil (Riet-Correa 2007). Although the pathogenesis of blackleg has not been definitely established, current dogma states that the animals become infected by ingesting spores from the pasture. After one or more replication cycles in the intestine, the spores are absorbed into the systemic circulation and get eventually phagocytized by macrophages within the striated musculature. When a traumatic injury occurs with a consequent decrease in redox potential, the bacteria proliferate and produce several potent toxins that are responsible for the clinical signs and lesions of the disease (Abreu \& Uzal 2016, Cooper \& Valentine 2016). Because of this proposed pathogenesis, black leg is frequently referred to as an endogenous infection.

Blackleg needs to be differentiated from gas gangrene, considered an exogenous infection that is usually associated with skin and/or mucosal wounds, which allow entry of spores or vegetative forms of the organisms involved into the tissues of the host (Abreu \& Uzal 2016, Silva et al. 2016, Abreu et al. 2017). Gas gangrene can be produced by one or more of the following clostridial species: Clostridium septicum, C. chauvoei, C. perfringens, $C$. novyi and C. sordelli. Gas gangrene has been described in several ruminant species including deer, associated with a variety of wounds such as those produced by surgery, accidental trauma, darting and parturition (Herron et al. 1979, Buxton 1994, MacKintosh et al. 2002, Silva et al. 2016).

Although black leg is mainly a disease of cattle, cases have been reported, albeit infrequently, in wild ruminants, including white-tailed deer (Odocoileus virginianus), reindeer (Rangifer tarandus), and wapiti (Cervus elaphus spp.) (MacKintosh et al. 2002). To our knowledge, however, black leg has not been described in free-range brown brocket deer (Mazama gouazoubira) before. This is a South American cervid that can be found in southern Brazil and the Bolivian Chaco. The population of this deer is declining due to illegal hunting, habitat loss and road killing (Duarte \& Reis 2012, Black-Decima \& Vogliotti 2016). This paper describes a case of blackleg in a wild brown brocket deer associated with a road accident injury.

\section{MATERIALS AND METHODS}

A juvenile male brown brocket deer was found on the side of a road in Southern Brazil after being hit by a car, and transported immediately to the Núcleo de Reabilitação da Fauna Silvestre of Universidade Federal de Pelotas (NURFS-UFPel) for examination and treatment. On arrival, approximately six hours after the accident, the animal had hyperthermia $\left(39.2^{\circ} \mathrm{C}\right)$, lethargy, dehydration and swelling of the left pelvic limb musculature. Support treatment with meloxicam and fluids was initiated, but the deer died 36 hours after arrival. The carcass was sent for necropsy to the Laboratório Regional de Diagnóstico. A full necropsy was performed immediately after death and samples of skeletal muscle from both thigs, skin, spleen, small and large intestine, rumen, reticulum, omasum, abomasum, liver, kidney, lung, heart and nervous system were collected, fixed by immersion in $10 \%$ buffered formalin and routinely processed for histology. Selected sections of muscle were stained with hematoxylin and eosin (HE) and Gram and processed by immunohistochemistry (IHC) for Clostridium perfringens, C. chauvoei, C. septicum, C. novyi and C. sordellii as previously described (Assis et al. 2005, Nyaoke et al. 2018). The primary antibodies were produced in rabbit against each of the clostridia species mentioned above (VDRM, Pullman/WA, USA). Positive controls included bovine tissues from which each of those clostridia had been isolated. No cross-reactivity was observed between these clostridial IHC reactions. Samples of rear leg muscles were aseptically collected and cultured on 5\% sheep blood agar in anaerobiosis, MacConkey agar and cooked meat media and incubated at $37^{\circ} \mathrm{C}$ for $48-72$ hours.

\section{RESULTS}

The carcass was in good nutritional condition; it had adequate amounts of fat reserves and was well fleshed. There was multifocal hemorrhage, edema and emphysema of the subcutaneous tissue and muscles of both pelvic limbs (Fig.1A). These lesions were more severe on the left side (Fig.1B). The anterior right limb had close, comminuted, complete fractures of the radius and ulna and severe hemorrhage of the soft tissues surrounding the fractured bones. A careful examination of the skin in this area did not reveal punctures.

Histologically, the muscle fibers of the pelvic limb showed coagulation necrosis, characterized by hypereosinophilia, hyalinization, loss of striations, and flocculation of cytoplasm (Fig.2A), vacuolation and hypercontraction bands. In addition, there was interstitial edema, hemorrhage (Fig.2B) and mild neutrophilic inflammatory infiltrate (Fig.2C). The blood vessels showed discrete, multifocal vasculitis with fibrinoid necrosis. Large gram-positive rods, many of them with sub-terminal spores were seen single and in clusters in the muscular interstitium and occasionally within myocytes and blood vessels. These organisms stain positively for Clostridium chauvoei IHC (Fig.2D), but negatively for the other clostridia tested. In the microbiological culture of the affected muscle fragment, there was no growth when incubated aerobically on MacConkey agar and blood agar. On cooked meet medium, gram-positive and sporulated rod-shaped bacteria grew. This organism was re-plated on blood agar in an anaerobic system (Probac do Brasil, Anaerobac ${ }^{\circledR}$ ). The colonies were surrounded by large zone of hemolysis. Gram-stained impression smear of those colonies revealed large gram-positive rods with oval, sub terminal or central spores. No other microorganisms were isolated from muscle samples of this animal.

\section{DISCUSSION}

A presumptive diagnosis of blackleg was based on gross, microscopic findings, and by isolation of an anaerobic sporulated gram-positive rod. This diagnosis was confirmed by detection of Clostridium chauvoei in muscle by IHC. Moreover, examination of IHC sections revealed that $C$. chauvoei was intimately associated with muscle lesions, which confirms that this microorganism was indeed responsible for the lesions observed.

In this case, trauma occurring when a car hit this deer was considered the likely triggering factor for blackleg. If this was so, the deer must have been harboring spores of $C$. chauvoei in the musculature before the accident and tissue anaerobiosis associated with muscle trauma triggered spore germination followed by a chain of events similar to those described for 

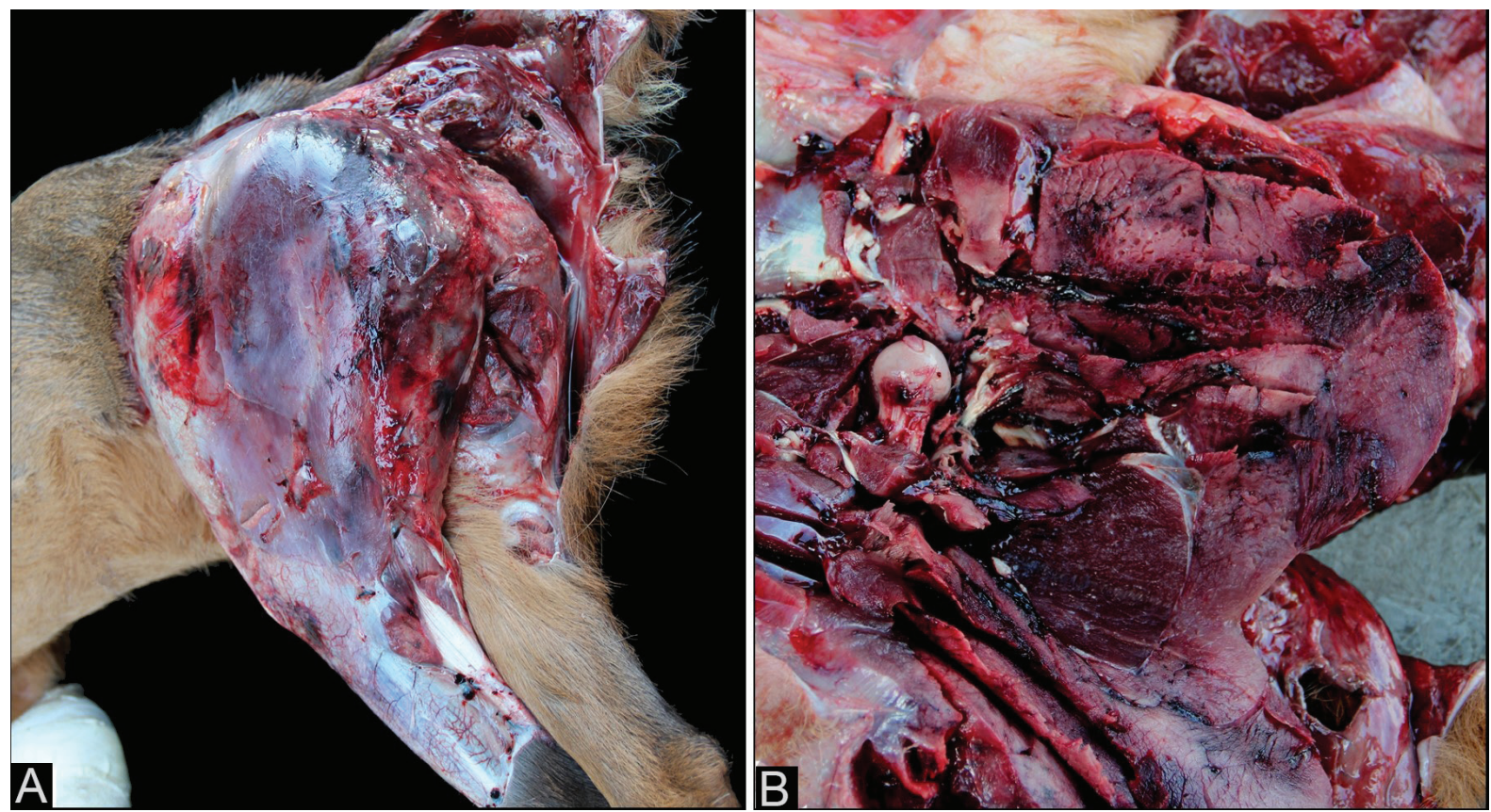

Fig.1. Brown brocket deer, male, left pelvic limb. (A) Musculature with increased volume and hemorrhage. (B) musculature whit hemorrhage, discrete discoloration, necrosis and gas bubbles.
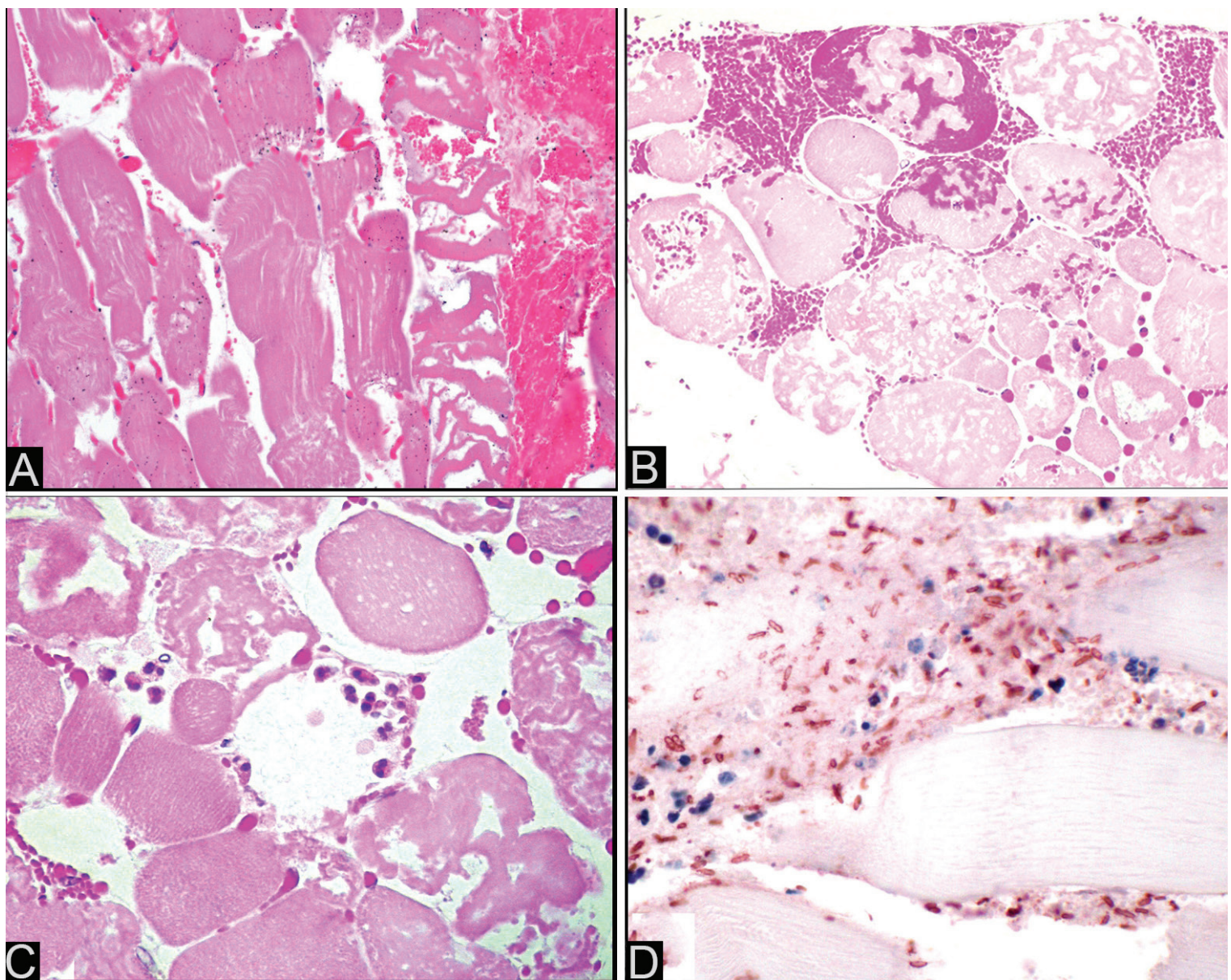

Fig.2. Brown-brocket-deer, skeletal muscle. (A) Longitudinal section of the muscular fibers showing segmental necrosis and hemorrhage. HE, obj.40x. (B) Degenerative changes in the muscle fibers with flocular necrosis, edema, hemorrhage. HE, obj.40x. (C) Discrete inflammatory infiltrate of neutrophils between the muscle fibers. HE, obj.40x. (D) Bacterial rods positive staining with anti-Clostridium chauvoei. IHC, 40x. 
blackleg pathogenesis in cattle (Abreu \& Uzal 2016, Silva et al. 2016, Abreu et al. 2017). The most severe injuries produced by the accident occurred in the front legs and yet, blackleg lesions were only observed in the rear legs. It is possible that spores were present only in the rear leg musculature and blunt trauma affected also these areas triggering spore germination. Alternatively, it is possible that spores were present initially in the front legs where bone fractures occurred and a small blackleg lesion developed in this area initially but it was not discovered during gross and microscopic examination. If this was the case, septicemia may have ensued with metastatic larger lesions occurring in the rear legs. The large muscular masses of the hind legs are amongst the most frequently affected in cattle with blackleg; the reason for this preference is unknown (Abreu et al. 2017).

Although C. chauvoei is best known for its role in blackleg, this microorganism can also be, albeit very rarely, part of the gas gangrene complex (Abreu \& Uzal 2016, Abreu et al. 2017). Although blackleg affects mostly muscle and gas gangrene tends to affect primarily sub-cutis, some overlap between both diseases may occur, and lesion location is not always conclusive in the differentiation of both diseases. In this case, however, no skin or mucosal lesions were seen, which rules out a diagnosis of gas gangrene.

The gross and microscopic lesions found in the deer of this study were very similar to those found in cattle diagnosed with blackleg, which also supports a similar pathogenesis between cattle and deer blackleg. Differential diagnoses considered in this case were gas gangrene and capture myopathy. They were ruled out based on clinical, gross and microscopic findings, while other bacterial myositis were ruled out based, microscopic, microbiological and IHC findings (Abreu et al. 2017).

Cattle production is the main economic activity of Rio Grande do Sul state (Pinto \& Coronel 2015), and the habitat of the brown brocket deer overlaps with areas of large cattle density (Rodrigues et al. 2014). Furthermore, cases of bovine blackleg were previously diagnosed in the area where the brown brocket deer of this report was found (Riet-Correa 2007). It is therefore possible that spores of $C$. chauvoei of bovine origin contaminated the pastures in the area and that this deer became contaminated by grazing in areas where cattle has been grazing before. Proximity of wild animals to livestock is a determining factor for the spread of several infectious diseases (Brahmbhatt et al. 2012, Gortazar et al. 2014) and this seems to have been the case with this deer.

\section{CONCLUSIONS}

Blackleg should be considered amongst the differential diagnoses in cases of myositis associated with muscular blunt trauma in brown brocket deer.

The close interaction between cattle and deer may have provided an opportunity for infection spillover from domestic to wild animals.

\section{REFERENCES}

Abreu C.C. \& Uzal F.A. 2016. Blackleg, p.231-242. In: Uzal F.A., Songer J.G., Prescott J.F. \& Popoff M.R. (Eds), Clostridial Diseases of Animals. Wiley Blackwell, Ames, IA. <http://dx.doi.org/10.1002/9781118728291.ch19>.
Abreu C.C., Edwards E.E., Edwards J.F., Gibbons P.M., Leal de Araújo J., Rech R.R. \& Uzal F.A. 2017. Blackleg in cattle: a case report of fetal infection and a literature review. J. Vet. Diag. Invest. 29(5):612-621. <http://dx.doi. org/10.1177/1040638717713796><PMid:28599620>

Assis R.A., Lobato F.C., Serakides R., Santos R.L., Dias G.R., Nascimento R., Abreu V.L., Parreiras P.M. \& Uzal F.A. 2005. Immunohistochemical detection of Clostridia species in paraffin-embedded tissues of experimentally inoculated guinea pigs. Pesq. Vet. Bras. 25(1):4-8. <http://dx.doi.org/10.1590/S0100736X2005000100002>

Black-Decima P.A. \& Vogliotti A. 2016. Mazama gouazoubira. The IUCN Red List of Threatened Species, Cambridge. <http://dx.doi.org/10.2305/IUCN. UK.2016-2.RLTS.T29620A22154584.en>

Brahmbhatt D.P., Fosgate G.T., Dyason E., Budke C.M., Gummow B., Jori F., Ward M.P. \& Srinivasan R. 2012. Contacts between domestic livestock and wildlife at the Kruger National Park Interface of the Republic of South Africa. Prev. Vet. Med. 103(1):16-21.<http://dx.doi.org/10.1016/j. prevetmed.2011.08.003 > <Mid:21907434>

Buxton D. 1994. Clostridial diseases, p.117-119. In: Alexander T.L. \& Buxton D. (Eds), Management and Diseases of Deer. Veterinary Deer Society, London.

Cooper B.J. \& Valentine B.A. 2016. Muscle and tendon, p.230-233. In: Maxie M.G. (Ed.), Jubb, Kennedy, and Palmer's Pathology of Domestic Animals. Vol.1. 6th ed. Elsevier, St Louis, MO. <http://dx.doi.org/10.1016/B9780-7020-5317-7.00003-5>.

Duarte J.M.B. \& Reis M.L. 2012. Plano de Ação Nacional para a Conservação dos Cervídeos Ameaçados de Extinção. Instituto Chico Mendes de Conservação da Biodiversidade, Brasília. 65p.

Gortazar C., Reperant L.A., Kuiken T., de la Fuente J., Boadella M., MartínezLopez B., Ruiz-Fons F., Estrada-Peña A., Drosten C., Medley G., Ostfeld R. Peterson T., VerCauteren K.C., Menge C., Artois M., Schultsz C., Delahay R., Serra-Cobo J., Poulin R., Keck F., Aguirre A.A., Henttonen H., Dobson A.P., Kutz S., Lubroth J. \& Mysterud A. 2014. Crossing the interspecies barrier: opening the door to zoonotic pathogens. PLoS Pathog. 10(6):e1004129. <http://dx.doi.org/10.1371/journal.ppat.1004129> <PMid:24945247>

Herron A.J., Garman R.H., Baitchman R. \& Kraus A.L. 1979. Clostridial myositis in a reindeer (Rangifer tarandus): a case report. J. Zoo Anim. Med. 10(1):3134. <http://dx.doi.org/10.2307/20094409>

Maboni F., Assis R.A. \& Vargas A.P.C. 2010. Ocorrência de clostrídios isolados de 1988 a 2007. Vet. Zootec. 17:343-347.

MacKintosh C., Haigh J.C. \& Griffin F. 2002. Bacterial diseases of farmed deer and bison. Rev. Scient. Tech., Off. Int. Epizoot. 21(2):249-263. <http:// dx.doi.org/10.20506/rst.21.2.1341><PMid:11974613>

Nyaoke A.C., Navarro M.A., Beingesser J. \& Uzal F.A. 2018. Infectious necrotic hepatitis caused by Clostridium novyi type B in a horse: case report and review of the literature. J. Vet. Diagn. Invest. 30(2):294-299. <http://dx.doi. org $/ 10.1177 / 1040638717737125><$ PMid:29224513>

Pinto N.G.M. \& Coronel D.A. 2015. Degradação ambiental nos municípios do Rio Grande do Sul e relação com os fatores de desenvolvimento rural. Revta Econ. Sociol. Rural 53(2):271-288. <http://dx.doi.org/10.1590/123456781806-9479005302005>

Riet-Correa F. 2007. Doenças bacterianas: carbúnculo sintomático, p.264-267. In: Riet-Correa F., Schild A.L., Lemos R.A.A. \& Borges J.R.J. (Eds), Doenças de Ruminantes e Equídeos. Vol.1. 3aㅗ ed. Pallotti, Santa Maria.

Rodrigues T.F., Cerveira J.F. \& Duarte J.M.B. 2014. Uso de áreas agrícolas por Mazama gouazoubira (Mammalia, Cervidae) no Estado de São Paulo. Iheringia, Série Zoologia 104(4):439-445. <http://dx.doi.org/10.1590/1678476620141044439445>

Silva R.O.S., Uzal F.A., Oliveira Junior C.A. \& Lobato F.C.F. 2016. Gas gangrene, malignant edema, p.243-254. In: Uzal F.A., Songer L.G., Prescott J.F. \& Popoff M.R. (Eds), Clostridial Diseases of Animals. John Wiley \& Sons, New Jersey. 